Л.М. Сакович, Г.Я. Криховецький, Я.Е. Небесна

Інститут спеціального зв'язку та захисту інформації

Національного технічного університету Украӥни

“Київський політехнічний інституту імені Ігоря Сікорського”, Київ

\title{
ОЦІНКА ВПЛИВУ МЕТРОЛОГІЧНОЇ НАДІЙНОСТІ ЗАСОБІВ ВИМІРЮВАНЬ НА ЧАС ВИКОНАННЯ ТЕХНІЧНОГО ОБСЛУГОВУВАННЯ ЗАСОБІВ СПЕЦІАЛЬНОГО ЗВЯЗКУ
}

У статті запропонований підхід до кількісної оцінки впливу метрологічної надійності засобів вимірювань на час виконання вимірювань значень параметрів засобів спеціального зв'язку при їх технічному обслуговуванні. У відомих роботах ичю обставину не враховують, щзо веде до заниження необхідного часу визначення реального технічного стану засобів спеціального зв'язку. Приведено приклад використання отриманих результатів для кількісної очінки збільшення часу вимірювань значень параметрів радіостаниії малої потужності при ї̈ технічному обслуговуванні.

Ключові слова: засоби вимірювальної техніки, метрологічна надійність, засоби спеціального зв'язку.

\section{Вступ}

Аналіз останніх досліджень і публікацій. Засоби спеціального зв'язку (ЗС3) безперервно удосконалюються в напрямку підвищення значень показників якості, що веде до збільшення кількості їх елементів [1], але час технічного обслуговування (TO) залишається без змін. Рекомендації щодо вибору засобів вимірювальної техніки (ЗВТ) для ТО та поточного ремонту ЗСЗ і військової техніки зв'язку приведено в [2,3], але без врахування впливу метрологічної надійності. Питання метрологічної надійності ЗВТ окремо розглянуто в [4, 5], а іiї вплив на час поточного ремонту кількісно оцінюється в $[6,7]$. Щомісяця виконують ТО-1 і щорічне ТО-2 3С3 3 інструментальною оцінкою їх реального технічного стану, але при цьому не враховують вплив метрологічної надійності ЗВТ на час виконання робіт.

Формулювання мети статті Мета статті - кількісна оцінка впливу метрологічної надійності 3ВТ на виконання вимірювань значень параметрів 3С3 під час їх ТO.

\section{Виклад основного матеріалу}

Метрологічна надійність - це властивість ЗВТ функціонувати при збереженні метрологічних та інших показників у заданих межах і режимах робити [4,5]. Внаслідок старіння елементної бази, вироблення технічного ресурсу, завершення періоду нормальної експлуатації та переходу ЗВТ до граничного стану зростає вплив їх метрологічної надійності на час виконання вимірювань значень параметрів 3С3 3 метою оцінки їх реального технічного стану в процесі ТО. Це ускладнює планування роботи фахівців ремонтних органів тому, що час виконання вимірювань значень параметрів 3С3 перевищує приведений в інструкціях з експлуатації і технічного обслуговування окремих зразків.

Особливість експлуатації ЗВТ обумовлена забезпеченням їх безвідмовності, переважно за прихованими метрологічними відмовами. Негативні наслідки використання ЗВТ з метрологічними відмовами можуть бути надзвичайно великими і важко передбачуваними. В якості показників метрологічної надійності ЗВТ використовують імовірність $\mathrm{P}_{\mathrm{i}}(\tau)$ збереження значень метрологічних характеристик у заданих межах протягом міжповірочного інтервалу $\tau$ $[4,5]$.

Необхідний рівень метрологічної надійності суттєво залежить від сфери застосування ЗВТ і обирається з умови забезпечення необхідної ефективності обслуговуваних технічних пристроїв. Як правило, цей рівень для робочих ЗВТ становить $0,85 \ldots 0,90$, а для зразкових $0,90 \ldots 0,99$ [5-7].

Кількісно імовірність збереження значень метрологічних характеристик ЗВТ в конкретних умовах експлуатації можливо оцінити за виразом [5-7]:

$$
\mathrm{P}_{\mathrm{i}}(\tau)=1-\mathrm{m} \cdot \mathrm{K}_{\mathrm{M}} \cdot \mathrm{K}_{\mathrm{C}},
$$

де еквівалентна кількості відмов при експлуатації

$$
\mathrm{m}=\frac{\tau \cdot \mathrm{K}_{\mathrm{B}}}{\mathrm{T}}
$$

$\mathrm{K}_{\mathrm{M}}$ - частка метрологічних характеристик, неохоплених вбудованим контролем;

$\mathrm{K}_{\mathrm{C}}$ - статистична оцінка коефіцієнта прихованих відмов, яка характеризує частку метрологічних відмов;

$\mathrm{K}_{\mathrm{B}}$ - середній коефіцієнт використання 3ВТ;

$\mathrm{T}$ - наробіток на відмову.

Значення $\tau$ отримують зі керівних документів метрологічного забезпечення обслуговуваних технічних об'єктів або із технічного опису ЗВТ. 
Відомо, що фахівець ремонтного органу безпосередньо займається ТО та відновленням ЗСЗ 900 годин на протязі року [8]. В такому разі коефіцієнт використання 3ВТ на пункті технічного обслуговування та ремонту кількісно дорівнює

$$
\mathrm{K}_{\mathrm{B}}=\frac{900}{8760}=0,103 .
$$

За результатами аналізу технічного стану та інструкцій 3 експлуатації конкретних зразків ЗВТ визначають $\mathrm{K}_{\mathrm{M}}$.

Значення $\mathrm{K}_{\mathrm{C}}$ залежне від призначення ЗВТ $\mathrm{i}$ при відсутності статистичних даних результатів експлуатації приладів - аналогів визначають за усередненими показниками [5-9], які змінюються від 0,1 при вимірюванні напруги до 0,24 при вимірюванні параметрів електронних радіоламп і напівпровідникових приладів .

Наробіток на відмову ЗВТ також беруть зі статистичних даних, а при їх відсутності із технічного опису приладів.

Середнє квадратичне відхилення оцінки імовірності збереження значень метрологічних характеристик ЗВТ розраховують за виразом [5-7]:

$$
\sigma=m \cdot K_{M} \sqrt{K_{C} \cdot\left(0,15 \cdot K_{C}+1 / m\right)} .
$$

Час виконання вимірювань значень параметрів ЗСЗ при їх ТО дорівнює

$$
\mathrm{T}_{\mathrm{TO}}=\sum_{\mathrm{j}=1}^{\mathrm{N}} \mathrm{T}_{\mathrm{nnj}},
$$

де $\mathrm{T}_{\mathrm{nnj}}$ - час перевірки параметра $\mathrm{j}$ на відповідність вимогам,

$\mathrm{N}$ - загальна кількість параметрів 3С3, що перевіряють під час ТО.

3 врахуванням метрологічної надійності ЗВТ отримуємо

$$
\mathrm{T}_{\mathrm{nn}}=\frac{\mathrm{t}_{\mathrm{n}}+\mathrm{t}_{0} / \prod_{\mathrm{i}=1}^{\mathrm{n}} \mathrm{P}_{\mathrm{i}}}{\prod_{\mathrm{i}=1}^{\mathrm{n}} \mathrm{P}_{\mathrm{i}}(\tau)}
$$

де $t_{n}$ - час підготовки ЗВТ та збирання схеми вимірювання;

$\mathrm{t}_{0}$ - час оцінки результату вимірювання параметра;

$\mathrm{P}_{\mathrm{i}}$ - ймовірність правильної оцінки результату вимірювань [7];

$\mathrm{n}$ - кількість ЗВТ для оцінки значення параметpa.

Розглянемо використання приведених результатів на прикладі ЗВТ, що використовують під час ТО найбільш масових 3С3 - радіостанцій малої потужності Р - 173[10].

Результати кількісної оцінки показників метрологічної надійності ЗВТ, що використовують при ТО Р - 173, приведено в табл. 1.

Таблиця 1

Кількісна оцінка показників метрологічної надійності засобів вимірювальної техніки

\begin{tabular}{|l|l|l|l|l|c|}
\hline \multicolumn{1}{|c|}{ ЗВТ } & $\tau$, год & $\mathrm{K}_{\mathrm{M}}$ & $\mathrm{K}_{\mathrm{C}}$ & $\mathrm{P}_{\mathrm{i}}(\tau)$ & $\sigma$ \\
\hline Г4 - 116 & 5000 & 0,3 & 0,20 & 0,989 & 0,187 \\
\hline В3 - 41 & 4000 & 1,0 & 0,10 & 0,978 & 0,148 \\
\hline Ч3 - 54 & 3000 & 0,5 & 0,16 & 0,976 & 0,217 \\
\hline В7 - 15 & 4000 & 1,0 & 0,10 & 0,978 & 0,148 \\
\hline Д - 5014 & 2000 & 1,0 & 0,23 & 0,899 & 0,319 \\
\hline Г3 - 102 & 5000 & 0,3 & 0,20 & 0,989 & 0,187 \\
\hline СК3 - 43 & 5000 & 0,1 & 0,16 & 0,997 & 0,054 \\
\hline
\end{tabular}

В цьому випадку найменш надійним є прилад Д - 5014, а найбільш надійним СК3-43.

Кількісна оцінка часу вимірювання параметрів P-173 з врахуванням метрологічної надійності 3ВТ приведено в табл. 2.

\begin{tabular}{|c|c|c|c|c|c|c|}
\hline \multirow[b]{2}{*}{ № } & \multirow[b]{2}{*}{ Параметр } & \multirow[b]{2}{*}{ 3BT } & & \multirow[b]{2}{*}{$\mathrm{p}$} & \multicolumn{2}{|c|}{ Час вимірювання } \\
\hline & & & & & Згідно інструкції & $\begin{array}{c}3 \text { врахуванням } \\
\text { надійності }\end{array}$ \\
\hline 1. & Чутливість приймача & $\begin{array}{c}\Gamma 4-116 \\
\text { B3-41 }\end{array}$ & $3 \times \mathrm{XB}$ & $\begin{array}{l}0,725 \\
0,834\end{array}$ & $25 \mathrm{xB}$ & $28 \times$ хв \\
\hline 2. & $\begin{array}{c}\text { Нестабільність часто- } \\
\text { ти }\end{array}$ & Ч3-54 & $10 \times \mathrm{x}$ & 0,9993 & $22 \times$ хв & $23 \times \mathbf{x}$ \\
\hline 3. & $\begin{array}{c}\text { Потужність передава- } \\
\text { ча }\end{array}$ & $\begin{array}{l}\text { B7-15 } \\
\text { Э9-4A }\end{array}$ & $3 \times \mathrm{xB}$ & $\begin{array}{c}0,85 \\
-\end{array}$ & $18 \times$ хв & 19 хв \\
\hline 4. & Струм споживання & Д5014 & $2 \times B$ & 0,95 & $10 \times$ хв & $12 \mathrm{xв}$ \\
\hline 5. & Девіація частоти & $\begin{array}{l}\text { Г3-102 } \\
\text { СК3-43 }\end{array}$ & $7 \mathrm{xB}$ & $\begin{array}{c}0,834 \\
0,9993\end{array}$ & $15 \times$ хв & 17 хв \\
\hline \multicolumn{5}{|c|}{ Загальний час виконання } & $90 \times \mathrm{xB}$ & 99 хв \\
\hline
\end{tabular}

Таблиця 2

Перелік операцій

щодо вимірювання параметрів радіостанцій Р-173 під час технічного обслуговування 
В такому разі реальний час вимірювання параметрів радіостанцій Р-173 з врахуванням метрологічної надійності засобів вимірювальної техніки на 10\% перевищує приведений в інструкції з іï технічного обслуговування [10].

\section{Висновки}

1. Врахування метрологічної надійності засобів вимірювальної техніки при оцінці часу виконання технічного обслуговування засобів спеціального зв'язку суттєво підвищує точність розрахунків необхідного часу на проведення вимірювань значень параметрів.

2. Отримані результати доцільно використовувати при плануванні роботи фахівців ремонтних органів під час оцінки реального технічного стану засобів спеціального зв'язку в процесі їх технічного обслуговування.

3. Подальші дослідження слід направити на оцінку впливу метрологічної надійності засобів вимірювальної техніки на показники якості відновлення засобів спеціального зв'язку 3 аварійним та бойовим походженнями.

\section{Список літератури}

1. Срохін В.Ф. Прогнозування основних характеристик перспективних радіостанцій силових структур / В.Ф. Срохін, В.М. Раєвський // Зв'язок. - 2005. - №3. C.61-64.

2. Кузнеиов І.Б. Організачія метрологічного забезпечення військ (сил): навч.посібн./.Б. Кузнецов, П.М. Ябловський. - К.: НУОУ, 2009. - 356 с.

3. Яковлев М.Ю. Підхід до вибору засобів вимірювальної техніки військового призначення для метрологічного обслуговування військової техніки зв'язку / М.Ю. Яковлев, С.В. Рижов // Військово-технічний збірник Академіі CB. - 2014. -- №1(10). - C. $118-127$.
4. Ким К.К. Метрология, стандартизаџия, сертификачия и електроизмерительная техника: учебное пособие/ К.К. Ким. - СПб.: Питер, 2008. - 368 c.

5. Кононов В.Б.Основи експлуатащії засобів вимірювальної техніки військового призначення в умовах проведення АТО : навч.посібн./ В.Б. Кононов, С.В. Водолажко, С.В. Коваль, А.М. Науменко, I.I. Кондрашова. - Х.: ХНУПС, 2017. - 288 с

6. Рижов С.В. Метод обтрунтування мінімально припустимого значення ймовірності оцінки результату перевірки параметрів / С.В. Рижов, Л.М. Сакович// Вісник НТУУ “КПІ". Серія Приладобудування. - 2017. Bun.54(2). - C.96- 106.

DOI: https://doi.org/10.20535/1970.54(2).2017.119562.

7. Яковлев М.Ю. Удосконалення методу завдання вимог до мінімально припустимого значення ймовірності правильної оцінки результату виконання перевірки під час діагностування / М.Ю. Яковлев, С.В. Рижов, Л.М. Сакович, П.Л. Аркушенко// Наука і техніка Повітряних сил Збройних Сил України. - 2017. - №4(29). - С. 137 - 142.

8. Сакович Л.М. Моделювання роботи апаратної технічного забезпечення / Л.М. Сакович, І.М. Гиренко // Сучасні інформачійні технології у сфері безпеки та оборони. - №1 (28). - 2017. - К.: Національний університет оборони України імені Івана Черняхівського. - C. 47 - 52.

9. Коваленко А.А. Сучасний стан та тендениї̈ розвитку комп'ютерних систем об'єктів критичного застосування / А.А. Коваленко, Г.А. Кучук // Системи управління, навігаиії та зв'язку. - Полтава . ПНТУ, 2018. Bun. 1(47). - C. 110-113.

10. Радиостанциия Р-173. Техническое описание и инструкиия по эксплуатации: ШИ 1.101.027 ТО. - М. : Воениздат, 1986. - $78 \mathrm{c}$.

Надійшла до редколегії 18.02.2018

Рецензент: д-р техн.наук. проф. В.В. Козловський, Інститут спеціального зв'язку та захисту інформації Національного технічного університету України "Київський політехнічний інститут імені Ігоря Сікорського”, Київ.

\title{
ОЦЕНКА ВЛИЯНИЯ МЕТРОЛОГИЧЕСКОЙ НАДЕЖНОСТИ СРЕДСТВ ИЗМЕРЕНИЙ НА ВРЕМЯ ВЫПОЛНЕНИЯ ТЕХНИЧЕСКОГО ОБСЛУЖИВАНИЯ СРЕДСТВ СПЕЦИАЛЬНОГО СВЯЗИ
}

\author{
Л.Н. Сакович, Г.Я. Крыховецкий, Я.Э. Небесная
}

В статье предложен подход к количественной оценке влияния метрологической надежности средств измерений на время выполнения измерений значений параметров средств специальной связи при их техническом обслуживании. $B$ известных работах это обстоятельство не учитывают, что ведет к занижению необходимого времени определения реального технического состояния средств специальной связи. Приведены пример использования полученных результатов для количественной оценки увеличения времени измерений значений параметров радиостанции малой мощности при ее техническом обслуживании.

Ключевые слова: средства измерительной техники, метрологическая надежность, средства специальной связи.

\section{EVALUATION OF METROLOGICAL RELIABILITY OF MEASURING INSTRUMENTS FOR THE DURATION OF MAINTENANCE OF COMMUNICATION SPECIAL}

\section{L.M. Sakovich, G.Ya. Krichovetsky, Ya.E. Nebesna}

The article proposes the approach to the quantitative assessment of the influence of metrological reliability of measuring instruments on the time of measuring the values of the parameters of the means of special communication during their maintenance. In known works, this circumstance is not taken into account, which leads to the understatement of the necessary time to determine the real technical state of means of special communication. An example of the use of the obtained results for the quantitative estimation of the increase in the time of measurement of the parameters of the radio station of low power during its maintenance is given

Keywords: means of measuring technique, metrological reliability, means of special communication. 